ДВНЗ «Тернопільський державний медичний університет

імені І. Я. Горбачевського МОЗ Украӥни»

\title{
ПРОБЛЕМИ ВИКОРИСТАННЯ ДОСВІДУ США $З$ ОРГАНІЗАЦІЇ ПРОФЕСІЙНОЇ ПІДГОТОВКИ МАЙБУТНІХ ЛІКАРІВ: УКРАЇНСЬКИЙ KOHTEKCT
}

\author{
I. Horbachevsky Ternopil State Medical University \\ PROBLEMS OF THE USA EXPERIENCE IMPLEMENTATION \\ IN ORGANIZATION OF FUTURE DOCTORS’ TRAINING: UKRAINIAN \\ CONTEXT
}

\begin{abstract}
Анотація. У статті обгрунтовано напрями врахування досвіду професійної підготовки лікарів США в медичній освіті України. На основі порівняльного аналізу програмних документів, які регулюють українську й американську систему підготовки майбутніх лікарів, виокремлено такі рекомендації: послідовне впровадження принципу автономії навчальних закладів, стимулювання наукової діяльності в межах університетів через створення науково-дослідних центрів, впровадження обов’язкової дослідницької складової до навчальних планів медичних університетів, створення системи державного освітнього кредитування, субсидування громадян з малозабезпечених сімей для отримання ними професійної освіти; стимулювання співзасновництва і багатоканального фінансування закладів професійної освіти, впровадження чітких правил відбору та зарахування абітурієнтів, започаткування вступних іспитів для вищих медичних навчальних закладів, що включають тести для оцінки психологічних особливостей та здібностей кандидатів, необхідних для майбутньої професійної діяльності, сприяння кооперації між навчальними і лікувально-діагностичними установами на всіх етапах професійної підготовки лікарів, утвердження концепції безперервного професійного розвитку та контроль за реальним її втіленням.
\end{abstract}

Ключові слова: медична освіта; США; Україна; Стратегія розвитку медичної освіти в Україні; університет; автономія.

Abstract. The article analyzes the perspective areas of the American experience implementation in the field of future doctors' professional training in Ukraine. On the basis of comparative analysis of program documents regulating the Ukrainian and American system of future doctors' training, the following recommendations have been singled out: consistent implementation of the principle of educational institutions autonomy, stimulating scientific activities within universities through the establishment of research centers, introduction of a mandatory research component into the curricula of medical universities, creation of a system of state educational loans, subsidizing applicants from low-income families, promotion of co-founding and multichannel financing of medical education institutions, implementation of clear rules for the applicants selection and admission, introduction of entrance examinations for higher medical institutions, including tests to assess the psychological characteristics and abilities of candidates required for the future; promotion of cooperation between educational and medical-diagnostic institutions at all stages of professional training of doctors, approval of the concept of continuous professional education and control over its actual implementation.

Key words: medical education; USA; Ukraine; “Strategy of development of medical education in Ukraine”; university; autonomy.

Вступ. Інтеграційні та глобалізаційні процеси у галузі вищої освіти загалом, входження української освітньої системи у світовий інформаційний простір вимагають кардинального оновлення цієї сфери нашої країни з урахуванням позитивного досвіду інших. Ці модернізаційні процеси знайшли відображення в Національній доктрині роз-

(C) T. I. Горпініч витку освіти (2002), «Про заходи щодо реалізації положень Болонської декларації в системі вищої медичної та фармацевтичної освіти» (2004), Плані дій щодо забезпечення якості вищої освіти України та її інтеграції в світове співтовариство на період до 2010 року (2007), Національній стратегії розвитку освіти на період до 2021 року (2013), Програмі розвитку вищої медичної освіти до 2015 року, За- 
коні України «Про вищу освіту» (2014), Стратегії розвитку медичної освіти (2019). Зокрема, у Законі України «Про вищу освіту» зазначено, що одним із завдань Центрального органа виконавчої влади у сфері освіти і науки є узагальнення світового досвіду розвитку вищої освіти. Важливим для національних закладів вищої освіти є сприяння інтеграції освіти, науки та інновацій у світовий освітньонауковий простір [1].

Однією з головних ідей Стратегії розвитку медичної освіти в Україні є прагнення ліквідувати ізольованість української медичної освіти і науки від світових тенденцій, надати можливість «користуватися найкращими здобутками світової медицини» [2]. Досягнення цілей, поставлених у Стратегії, $€$ можливим через вивчення міжнародного досвіду щодо різних аспектів функціонування системи медичної освіти (якісного відбору і вимог до зарахування у заклади вищої медичної освіти, визначення ключових компетентностей медика, складання новітніх освітніх програм і навчальних планів тощо) [2]. Таким чином, можливість і потребу критичного осмислення й адаптації зарубіжного досвіду в українській медичній освіті декларовано у важливих законодавчих та програмних документах.

Мета дослідження - вивчення проблем використання досвіду США з організації професійної підготовки майбутніх лікарів в Україні.

Методи дослідження. Для досягнення мети використано теоретичні та емпіричні методи дослідження, зокрема порівняльно-історичний метод дослідження освітніх документів, який дав можливість розглянути в ретроспективі генезу системи медичної освіти США; контент-аналіз для аналітичного опрацювання літератури; компаративний аналіз для встановлення спільних і специфічних ознак у системі професійної підготовки лікарів у США та Україні з метою визначення доцільності застосування американського педагогічного досвіду в національних умовах; пошуково-бібліографічний для вивчення та систематизації джерельної бази (науково-педагогічної, методичної літератури, нормативно-правових документів).

Результати дослідження. Проведене дослідження професійної підготовки майбутніх лікарів в університетах США дало можливість здійснити іï порівняльний аналіз із українським досвідом, виявити у цих процесах спільні та відмінні властивості, що, на нашу думку, зумовлені комплексом чинників різноаспектного характеру, та оцінити можливість і специфіку впровадження досвіду США у вітчизняні реалії.

Варто зазначити, що сьогодні в українській медичній освіті й практиці розпочато масштабні трансформації фінансового, структурно-організаційного та управлінського характеру. Потреба в цих перетвореннях стала очевидною в контексті кризових явищ, які назріли ще з радянських часів і не були повністю викорінені через невдалі кроки в галузі освітньої політики, а головне - відсутність бажання та певне упереджене ставлення до запозичення досвіду інших країн. Без сумніву, процес такого запозичення вимагає значної праці з порівняльного вивчення умов України і країн, чий досвід вивчається, стратегічного осмислення особливостей його впровадження і прогнозування імовірних труднощів, що можуть виникнути. Це $\epsilon$ складним і непопулярним завданням, якого уникає багато політичних сил. Ухвалення Кабінетом Міністрів України Стратегії розвитку медичної освіти в Україні 27 лютого 2019 р., запропонованої Міністерством охорони здоров'я, стало важливим зрушенням на шляху реформування галузі. Автори документа зазначають, що впровадження Стратегії допоможе за 10 років підняти українську медичну освіту до рівня розвинених держав [2].

Цікаво, що аналіз головних положень згаданого документа дає можливість простежити багато аналогій $з$ американськими організаційними, фінансовими і теоретико-дидактичними засадами функціонування медичної освіти. Сучасний стан речей в американській системі підготовки лікарів $\epsilon$ результатом тривалих, майже столітніх, перетворень, відправною точкою яких було визнання пріоритетності життя та здоров'я кожного громадянина, а головною ціллю - створення якісної медичної спільноти. Для осмислення спільних та відмінних рис американської та української систем медичної освіти за основу візьмемо Стратегію розвитку медичної освіти в Україні як головний програмний документ та сукупність американських нормативних актів, концепцій, наукових статей директивного характеру.

Пацієнтоцентричність $є$ головним принципом організації американської медичної освіти й практики, затвердженим низкою законодавчих актів, спрямованих на захист приватності пацієнта, його базових людських прав, зменшення кількості лікарських помилок, попередження недоліків систем охорони здоров’я і страхової медицини. Аналогіч- 
но, як згадується в Стратегії розвитку медичної освіти в Україні, головна цінність медичної системи - людина, а гуманістичне призначення медицини є відправною точкою надання медичних послуг.

У США рівень кваліфікації медичного працівника виступає основою якісної медичної допомоги. Це твердження закріплено в багатьох документах, як наприклад, звітах Ради з акредитації. Якість підготовки працівника стає також і центральним положенням української системи підготовки лікаря: як зазначено в Стратегії, кожен медичний працівник повинен бути вмотивованим висококваліфікованим фахівцем.

Академічна свобода й автономія університетів, які випливають 3 децентралізованості американської медичної освіти, є основою медичної освіти у США. Високий рівень академічної культури, який забезпечується усталеними традиціями університетів, де вона є нормою, існуванням Кодексів честі університетів, високою мотивацією студентів, розвитком навичок академічного письма студентів.

3 прийняттям Стратегії розвитку медичної освіти в Україні та як наслідок супутніх трансформаційних процесів автономія університетів й академічна свобода стають основою функціонування освітньої системи. Відбувається формування нового рівня академічної культури, який сприятиме академічній доброчесності, відкритості для співпраці, обміну досвідом.

У США важливим аспектом є стимулювання розвитку науки, як на федеральному рівні, так і на рівні окремих штатів, які здійснюють контроль за виконанням загальнодержавних і місцевих програм розвитку науки, створюючи власні регіональні плани розвитку різних напрямів наукової діяльності. Кожен штат має свій стратегічний план розвитку науки й технологій, який формується під суттєвим впливом приватних корпорацій і відображає знання й потреби місцевих ринків продукції та послуг [3].

Стратегія розвитку медичної освіти в Україні аналогічно проголошує і законодавчо закріплює пріоритетність стимулювання наукових досліджень, інтеграції навчання і науки. Загалом цей документ суттєво зачіпає питання фінансування медичної освіти. Зокрема, йдеться про впровадження програм фінансування найбільш перспективних наукових досліджень у медичній сфері, обраних на конкурсних засадах, заснування опорних центрів для проведення наукових досліджень, стимулювання співпраці закладів освіти й охорони здоров’я у галузі наукових досліджень і достатнє фінансування галузей медичної освіти і практики з боку держави загалом. Значне фінансування галузей охорони здоров'я й медичної освіти притаманно для американської системи підготовки лікарів (за сумами видатків на сферу охорони здоров’ я США займає перше місце у світі 9800 доларів на душу населення (2016)).

У США, згідно з вказівками Ради з акредитації медичної освіти, компетентнісний підхід $є$ основою підготовки майбутніх лікарів, у межах якого виділяють такі шість ключових компетентностей, як: догляд за пацієнтами, медичні знання, міжособистісні та комунікативні вміння, практично-зорієнтоване навчання, професіоналізм, системно-зорієнтована практика. В Україні, хоч уже склалася система фахової підготовки лікаря на засадах компетентнісного підходу, саме в Стратегії закцентовано на комунікативній та цифровій компетентностях медичних працівників. Окрім цього, документом передбачається розробка галузевої системи кваліфікацій, професійних стандартів.

У США з 2005 р. понад 75 \% медичних навчальних закладів займаються постійним оновленням навчальних планів на основі ретельного експертного аналізу. Згідно зі Стратегією, передбачено розробку університетами нових освітніх програм та навчальних планів з урахуванням міжнародного досвіду.

Важливими є і положення, які стосуються клінічних баз навчання. У США університетські клініки виступають основною ланкою додипломного та післядипломного навчання лікарів. В Україні в межах реформи передбачено налагодження якісної співпраці закладів вищої медичної освіти з класичними та технічними університетами з подальшим створенням потужних регіональних університетів з медичними факультетами в їх структурі, стимулювання розвитку університетських клінік для здійснення інноваційних наукових досліджень та забезпечення практичної підготовки студентів.

Цінним джерелом запозичення досвіду є власне робота з абітурієнтами і студентами. У США важливим досягненням є правильна політика відбору до закладів вищої освіти поряд з високим рівнем вимог до зарахування на медичні спеціальності, підкріпленим грунтовними соціо- та психометричними дослідженнями. Контроль за навчальними досягненнями студентів, який є основою американської медичної освіти, відзначається високою 
якістю. Тестові матеріали для контролю на всіх етапах навчання проходять ретельну багатоетапну перевірку експертами у відповідній галузі. Самостійне навчання $є$ однією з переваг американської освіти загалом, основою якого $є$ автономія студента. Гнучкість способів, методів, темпів, форм навчання дає змогу враховувати індивідуальні особливості студента, а головне - готують студента до безперервної професійної освіти.

Згідно зі Стратегією, в Україні відбудеться суттєве підвищення вимог до вступників до медичних навчальних закладів з урахуванням міжнародного досвіду. Цінними нововведеннями мають стати впровадження програм підготовки магістрів з медичних та фармацевтичних спеціальностей на базі ступеня молодшого бакалавра інтегрованого природничо-математичного спрямування (біологія, фізика, математика, хімія), постійний моніторинг задоволеності студентів якістю освіти, соціально-економічного стану їх родини, кар’єрних планів тощо, удосконалення процедури тестування, оновлення бази українських тестових завдань для єдиного державного кваліфікаційного іспиту розроблення положення про роботу експертів з формування бази екзаменаційних завдань. Заплановано впровадити суворий контроль за результатами оцінювань навчальних досягнень студентів зі сторони експертів, громадськості, налагодження нормативної бази для взаємного визнання результатів оцінювання з іноземними державами.

Варто згадати, що, згідно зі Стратегією, відбуватиметься Стимулювання підвищення рівня знання англійської мови викладачами, забезпечення достатніх ресурсів для вивчення англійської мови; запровадження програм навчання та стажування у закордонних університетах та лікувальних закладах, участі у міжнародних конференціях для викладачів та аспірантів, стимулювання публікацій у журналах, що входять до «Scopus» та/або «Web of Science».

Значні трансформації відбудуться і на післядипломному етапі навчання лікаря. Зокрема, заплановано реформування процедури проходження інтернатури (нові програми навчання, ротаційний принцип, новий механізм фінансування, зменшення кількості медичних спеціальностей в інтернатурі), створення всеукраїнського рейтингу студентів для проходження інтернатури та національного реєстру інтернатури зі спеціальностями та базами іiї проходження.
Цінним нововведенням стане запровадження етапу резидентури з визначенням переліку спеціальностей, тривалості навчання, нових вимог щодо зарахування і проходження резидентури й домовленість про взаємовизнання резидентури 3 державами-членами ЄС для забезпечення академічної і професійної мобільності, впровадження системи безперервного професійного розвитку 3 якісним визначення вимог до його провайдерів, умов фінансування.

В основі цих перетворень чітко відстежується спроба завозити досвід США, де ще з 1940-х років етап резидентури став обов'язковим для ліцензування молодого фахівця. Автономія університетів і програм навчання дала змогу розробити оптимальну модель ротацій та змістового наповнення програм резидентури в межах кожного навчального закладу. 3 1950-х років концепція безперервного професійного розвитку, зумовлена необхідністю ознайомлювати лікарів з новинками фармацевтичної індустрії та лікувальними технологіями, стала умовою сталого фахового вдосконалення медичних працівників [4]. Розмаїття підходів, форм і методів підвищення кваліфікації $є$ визначальною особливістю американської медичної освіти.

Система рейтингу студентів, викладачів, лікарів, навчальних закладів, їх ранжування за різними релевантними показниками є розповсюдженим iнструментом професійного відбору, стимулювання конкурентності в США. Полікультурність американської освіти, залучення випускників з інших країн і стимулювання запозичення досвіду американськими фахівцями в інших країнах, закріплено на законодавчому рівні і мають статус офіційної освітньої політики в США.

Отже, можна стверджувати, що багато трансформаційних ідей для реформування української медичної освіти було запозичено з американського досвіду. До головних принципів, які лягли в їх основу, належать: 1) створення нової академічної культури викладачів і студентів шляхом стимулювання якісного професійного відбору, сумлінного навчання, ініціативності та негайного викорінення проявів недоброчесності; 2) інтернаціоналізація медичної освіти через зорієнтованість на світові стандарти в навчанні і контролі, забезпечення академічної мобільності; 3) акцент на комунікативну сторону взаємин «лікар-пацієнт».

Варто зазначити, що такі перетворення неможливі без одночасної перебудови системи цінностей 
і культури студентів, яка стане відправною точкою трансформацій в українській медичній освіті. Окрім цього, надійно сформовані професійні цінності студентів сприятимуть самовідтворенню новоствореного академічного середовища, незалежно від зовнішніх фінансових чи політичних чинників.

Важливим нововведенням стало й реформування етапу зарахування до медичних закладів освіти. Так, у ході вступної кампанії 2018 р. Міністерство освіти і науки за пропозицією Міністерства охорони здоров'я встановило мінімальний бал зовнішнього незалежного оцінювання (ЗНО) на рівні 150 балів. У результаті кількість вступників зменшилася на 28 \% порівняно з минулим роком, що позначилося на рівні їх підготовки. Вважаємо важливим також включення до запитань $3 \mathrm{HO}$ тестів, які б перевіряли когнітивні вміння абітурієнтів, критичність, науковість, аналітичність, прогностичність їх мислення.

У цьому контексті важливою є профорієнтаційна робота в школі. Фахові знання та професійно значущі когнітивні вміння закладаються вже на етапі шкільної освіти. У зв’язку з цим раннє професійне самовизначення сприятиме формуванню ще до етапу підготовки до ЗНО.

У межах реалізації Стратегії медичної освіти в Україні в медичних університетах буде впроваджено масштабну реформу академічної доброчесності. За словами I. Совсун, соціологічні дослідження показують, що зараз приблизно 90 \% студентів українських університетів списують на іспитах. 3 метою подолання цієї проблеми, а також для усунення питань плагіату в дисертаціях МO3 планує додати до контрактів з ректорами університетів пункт про зобов’язання стежити за академічною доброчесністю. Вважаємо, що оскільки ректори можуть виконувати цю вимогу формально, важливою є розробка механізму контролю за виконанням цього зобов’ язання.

Крім того, розвиток академічної доброчесності не повинен починатися на етапі вищої освіти. Його основи слід закладати з першого контакту 3 формальною освітою дитини. Мотивація на чесну

\section{Список літератури}

1. Про вищу освіту : Закон України // Офіційний портал Верховної Ради України. - URL : http://zakon5.rada. gov.ua/laws/show/1556-18.

2. Стратегія розвитку медичної освіти в Україні / Міністерство охорони здоров’я України. - 41 с. - URL : http://moz. gov.ua/uploads/1/7113-medical_education_analytics.pdf. конкуренцію, професійну доброчесність повинна формуватися на кожному занятті на всіх етапах здобуття освіти школярем чи студентом.

Висновки та перспективи подальших досліджень. Таким чином, реформування медичної освіти в Україні спрямоване на створення якісно нової академічної спільноти. Стратегія розвитку медичної освіти як програмний документ цих трансформацій декларує багато нововведень, притаманних для американської підготовки лікарів. Узагальнюючи пропоновані нововведення та авторські рекомендації, виокремимо такі напрями змін, які, на нашу думку, є запорукою модернізації української медичної освіти з урахуванням досвіду США: а) підвищення академічної культури студентів і викладачів; б) гуманізація надання медичних послуг; в) підсилення фінансування галузей медичної освіти і охорони здоров’я; г) розширення мережі університетських клінік; г) підвищення вимог до зарахування на медичні спеціальності; д) впровадження світових стандартів в оцінювання навчальних досягнень студентів; е) стимулювання наукової діяльності студентів; є) впровадження концепції безперервного професійного розвитку.

При впровадженні згаданих інновацій варто враховувати відмінності між етнічними, соціальними, економічними особливостями населення України і США через їх ретельне вивчення за рахунок інструментарію психології, економіки, соціології. Також варто пам'ятати, що згадані трансформації повинні мати системний характер, тобто торкатися й інших дотичних галузей державної політики (економіки, медицини, шкільної освіти, соціальної роботи тощо), і відбуватися синхронно на всіх етапах професійного становлення фахівця.

Проведене дослідження не вичерпує всіх аспектів окресленої проблеми. На нашу думку, у згаданому контексті потрібне подальше поглиблене порівняльне вивчення закономірностей навчання лікарів на різних етапах професійної підготовки, виокремлення позитивних аспектів законодавчого забезпечення навчального процесу в американських медичних школах.

3. Health Research and Quality Act. - Washington, 1999. -24 p.

4. Medical education. Encyclopaedia Britannica. - URL : https://www.britannica.com/science/medical-education. 


\section{References}

1. Pro vyshchu osvitu: Zakon Ukrainy [On higher education: Law of Ukraine]. Official portal of the Verkhovna Rada of Ukraine. Retrieved from: http://zakon5.rada.gov.ua/ laws/show/1556-18.

2. Stratehiia rozvytku medychnoi osvity v Ukraini [Strategy of the Development of Medical Education in Ukraine]. Ministry of Health of Ukraine. 41. Retrieved from: http://moz.gov.ua/uploads/1/7113-medical_education_ analytics.pdf.

3. Health Research and Quality Act (1999). Washington. 4. Medical education. Encyclopaedia Britannica. Retrieved from: https://www.britannica.com/science/ medical-education.

Електронна адреса для листування: gorpinich@tdmu.edu.ua 